\title{
APPLICATION OF CRITICAL DISCOURSE ANALYSIS (CDA) METHODS TO IMPROVE THE ABILITY OF STUDENTS UNDERSTAND DESCRIPTIVE TEXT
}

\author{
I Wayan Numertayasa \\ Indonesia Education and Literature Departement, \\ Sekolah Tinggi Keguruan dan Ilmu Pendidikan Suar, Indonesia \\ Email:numertayasawayan@gmail.com
}

\begin{abstract}
The present classroom action research aimed to (1) determine the critical discourse analysis method to improve the seventh E grade students of SMP Negeri 1 Susut in comprehending descriptive text, (2) determine the syntaxes of the critical discourse analysis method to improve the seventh E grade students of SMP Negeri 1 Susut in comprehending descriptive text,, (3) determine the responses of the seventh E grade students of SMP Negeri 1 Susut in comprehending descriptive text during the application critical discourse analysis method. The type of the present research is the Classroom Action Based Research (CAR). The subjects were VIIE grade students of SMP Negeri 1 Susut that consist of 33 people. Data collection methods used in this research are the method of observation, tests and questionnaires (questionnaire). Data were analyzed using two (2) analysis model, namely qualitative and quantitative descriptive analysis. The result of this study is the Application of Critical Discourse Analysis (CDA) can improve the ability to understand the descriptive text at seventh E grade students of SMP Negeri 1 Susut in the academic year 2015/2016. It can be seen from the students' ability to understand the text from the intial data to the first cycle with an average yield of 17,55 and from the first cycle to the second cycle increase in average yield of 14,64. In accordance with these findings suggested, results of this research can be considered to conduct the study with the same study and deeper.
\end{abstract}

Keyword: Critical Discourse Analysis method, descriptive text

\section{Introduction}

Based on the results observation the researchers did on the field on August 5, 2015 at SMP Negeri 1 Susut, Sub Susut, Bangli regency. Results of field observations of speakers, namely, one Indonesian teachers who teach in class VII named Made Susy Aryani, S.Pd. He stated that in SMP Negeri 1 Susut are eight classes VII comprising VII A grade to grade VII H each class is made up of 33 people and the curriculum applied in SMP Negeri 1 Susut are curriculum 2013.

Informant also explained that Curriculum 2013 is a text-based curriculum, in the curriculum of 2013 students are required to understand the material, active in the process of discussions and presentations as well as having good manners and discipline are high. In the process of teaching and learning that takes place there are still some obstacles that are often found by the speakers one of which is the ability to understand the descriptive text of students is still relatively low. It can be seen from the level of comprehension scores obtained by students is still below the average prescribed, namely 68 for the Indonesian subjects.

The low scores obtained by students in grade VIIE due monotonous way teachers teach. Teachers teach only relied on existing examples in the book thus indirectly make learning student becomes too monotonous and boring that ultimately resulted in students being less value or below a predetermined KKM.

The method used by the teacher is the inquiry method. Inquiry means investigation (Sumiati and Asra, 2007: 103). Learning with the inquiry method involves the student to follow a more active role in learning. However, there are obstacles encountered when using this method is that not all students have the same level of activity so that it affects the learning process. Students will feel comfortable following the lesson with this method, if students really have an appropriate level of activity. Meanwhile, students who have a level of activity that will result in the student feel less saturated in the following study so the effect on the value.

Learning process be applied by teachers in the classroom has been implemented in accordance with the method of the inquiry but, in the learning process of teachers are still not able to describe his method of inquiry to the fullest. It can be seen from some learning steps are not in accordance with the method of inquiry. Therefore, teachers should have been more aware of the methods applied in the classroom so that students learn more pleasant atmosphere. In addition teachers should implement a new way of teaching and learning so that students do not get bored and students easier to understand the material presented by the teacher. To avoid the boring learning environment of students will be better if the inquiry method is added with other learning methods. 
In the 2013 curriculum wearing a dialectical view is not structural, it means the text is not only seen by sight only seen by structural or formal view only, but the text is seen by structural and functional view is often called a critical view. Therefore, the authors propose Critical Discourse Analysis (CDA) Methods to improve the ability of students to understand the descriptive text in class VIIE SMP Negeri 1 Susut.

Critical Discourse Analysis is not a method of learning, but the Critical Discourse Analysis is a technique to identify, understand, organize, and prepare descriptive text. CDA methods in line with the curriculum in 2013 equally use dealiktis view.

In studies that have been conducted critical discourse analysis method (CDA) dibatisi only at the level of understanding the text only. There is a significant relationship between understanding and reasoning, that is to understand a discourse or text first discourse or text are analyzed to find out whether the purpose and intent of discourse or discourse or text so that the text is easy to understand.

There are several types of critical discourse analysis (CDA), such as CDA model of Theo Van Leeuwen, Sara Mills models CDA, CDA models Teun A. Van Dijk and CDA model of Norman Fairclough. Discourse Analysis theories used in the study which has been done is the theory of discourse analysis of Teun A. Van Dijk.

Van Dijk (in Eriyanto, 2001: 224) states that depicted discourse has three dimensions or building that is, text, social cognition, and social context. The text under study is how to structure the text and discourse strategies used to confirm a specific theme, social cognition studied is the process of text production, and social context that is learning something that flourish in the community will be a problem is found or encountered. The point analysis Van Dijk is to combine the three dimensions of discourse into a single unified analysis.

Furthermore Dijk (in Rosidi, 2007: 10) treat discourse as a structured entity. Therefore, the approach offered was opposite of scrutiny on three levels of discourse structure, namely: supra structure, microstructure and macro structures (superstructure, micro structure, andmacrostructure).

Supra structure refers to the framework of a discourse or schematic, such as the prevalence of speech or writing that starts from the introduction, followed by the contents of the subject, followed by conclusions, and ended with the closing. The part where the precedence, and which part will be regulated in the interests dikemudiankan discourse maker. Microstructure refers to the local significance (local meaning) discourse. It can be extracted from the aspect of semantics, syntax, stilistika, and rhetoric. Macro structure pointed to padamakna whole (global meaning) that can be observed from the theme or topic raised by the use of language in discourse.

According to Dijk (in Numertayasa, 2013: 62) to analyze overall structural components of discourse, can be termed social cognition discourse maker. Theoretically, this statement is based on the reasoning that the ways of looking at reality will determine the pattern and structure of the resulting discourse. If desired until the particulars of how certain discourse was entangled with the social structure and knowledge developed in the community, it is critical discourse analysis should be followed by social analysis.

Based on the exposure can be concluded that in view of the critical theory or Teun van Dijk, the discourse consists of supra structures, micro and macro. It shows discourse can not be separated from the action, text, context, historical, power, and ideology that surrounds. By analyzing the overall structural components of discourse, can be termed cognition (knowledge, ideology, interests, and so on) social discourse maker. Therefore, it is very relevant critical theory used in analyzing discourse.

On this basis as a concrete step to support students' understanding of descriptive text, it is very fitting Critical Discourse Analysis method applied in the classroom especially in understanding a text and understand mengkhusus more descriptive text VIIE grade students of SMP Negeri 1 Susut.

\section{Research Methods}

As for the subject of a Class Action Research is all VIIE grade students of SMP Negeri 1 Susut amounting to 33 students. The object of classroom action research is the ability of students to understand the descriptive text, learning steps with CDA method, and a student's response to the application of critical discourse analysis method. This class action research is in SMP Negeri 1 Susut, Susut District of Bangli. This classroom action research using a model of Kurt Lewin. This model has a concept that consists of four components, namely: 1) Planning, 2) action 3) Observations, 4) Reflection.

Data descriptive text students' ability to understand the analyzed qualitatively. Indicators of success is that the students are able to achieve an average score of at least 75 , the absorption of students a minimum of $65 \%$ and a minimum of $85 \%$ classical completeness. The formula used to measure the ability to understand the text descriptive score is:

$$
\text { Value }=\frac{\text { total acone of atudents }}{\text { number of maximum scone }} \times 100
$$


As for the data steps learning method Critical Discourse Analysis (CDA) is applied based on syntaxsyntax CDA which is then compiled by exercising their Lesson Plan. Student response data to the CDA method measured using a Likert scale. Questionnaires were given compiled with the option strongly agree, agree, disagree (TS) and strongly disagree (STS). The following is a table of criteria scoring students' responses to a given learning model.

\section{Results And Discussion}

\section{Results}

Based on the observation data analysis (preliminary data), the first cycle and the second cycle, it was found that the average person's ability to understand the Indonesian descriptive text on preliminary data amounted to 55.39 which are in the range of 47.5 to 62.4 are classified as category enough, then average the ability to understand Indonesian descriptive text in the first cycle of 72.94 which are in the range of 62.5 to 77.4 in both categories, while the average capacity to understand the Indonesian descriptive text on the second cycle is 87.58 which are in the range of 77.5 to 100 with very good category. As for the classical completeness to the preliminary data of $9 \%$ and in the first cycle was about $61 \%$ and then the classical completeness in the second cycle to $100 \%$ so that an increase in the classical completeness of the initial data of students to the first cycle, from the first cycle to the second cycle.

Table 1. Summary of Data Capabilities Understanding Descriptive Text Indonesian Students in SMP Negeri 1 Susut VIIE Academic Year 2015/2016

\begin{tabular}{c|ccc}
\hline \multirow{2}{*}{ RESULTS } & \multicolumn{3}{c}{ CYCLE } \\
\cline { 2 - 4 } & $\begin{array}{c}\text { Preliminary } \\
\text { Data }\end{array}$ & I & II \\
\hline Average Learning Outcomes & 55,39 & 72,94 & 87,58 \\
Classical completeness & $9 \%$ & $61 \%$ & $100 \%$ \\
\hline
\end{tabular}

\section{Discussion}

Based on the problems that the author encountered in the field and the application of methods in the class CDA VIIE and analysis of research data that researchers do, it turns CDA method can improve the ability to understand the descriptive text VIIE grade students of SMP Negeri 1 Susut. Increasing students' ability to understand students descriptive text of the preliminary data on the observation of 55.39 increased to 72.94 in the first cycle and became 87.58 at the end of the second cycle.

The success achieved in this study, namely, the method of CDA, students more easily determine the structure of descriptive text that consists of a description of the part and the general description, students are also able to dictate the terms of the text consists of the introduction, contents, cover, and conclusions (superstructure) , a method of CDA, students are able to determine the local meaning of a text that can be observed from the choice of words, sentences, and the style used by a descriptive text in this case students more easily define any word can be used in the descriptive text, such as the verb active and adjectives (micro structure), with CDA method, students more easily determine the general meaning of a text that can be observed on the topics or themes raised in the descriptive text that dianalisinya (macro structure). This is in accordance with the theory of Van Dijk (in Rosidi, 2007: 10) that treats discourse as a structured entity. Therefore, the approach offered was opposite of scrutiny on three levels of discourse structure, namely: supra structure, microstructure and macro structure (super structure, micro structure, and macro structure).

Furthermore, through CDA students not only how to fill in the descriptive text. Moreover, students also know how messages in the descriptive text conveyed through words, phrases, and sentences that are used in the descriptive text and the method CDA students more easily determine the structure or framework that compose a text. This corresponds to the approach introduced by Van Dijk. According to Dijk (in Eriyanto, 2001: 221) study of discourse is not enough just based on its analysis of the text simply because the text is only the result of a production practices must also be observed and this is also in accordance with the opinion expressed by Eriyanto (in Sobur, 2009: 68) which states that by looking at how the building structure of the language, more analysis to see the hidden meaning of a text.

Furthermore, the success achieved, namely the method CDA learning spirit of students is increasing, in this case the motivation are increased because students feel challenged and should prepare themselves to the maximum, the students also prepare themselves with more leverage in learning Indonesian lasting or will be comes particularly in understanding a text and understand mengkhusus more descriptive text. This is supported by a statement from Eriyanto (2001: 18), namely, the realm of textual analysis studies. Discourse analysis included in the critical research paradigm, a paradigm of thinking see the message as a question of power so that the text message is seen as a form of domination and hegemony of one group to another group. 
The steps of the application of methods CDA writers do in the classroom is as berikut.Kegiatan initial VIIE begins with preliminary activities, in this case teachers begin learning with a greeting to the students and the students also responded greeting given by the teacher, then the teacher did attendance for determine the level of attendance from the students themselves, after attendance researchers conducted apersepsi by questioning directed by researchers associated with text descriptions. After the introductory activity, followed by Main Activity.

In the present, the researchers directly measure the ability of students to understand the descriptive text using observation sheet. Once the core activities, namely dilanjutan last activity Closing Activities. In this concluding activity students with the guidance of researchers concluded the subject matter of the structure of the description text, then students work deberikan written test, students listen to the strengthening of researchers and students listened to the last follow-up information on the plan next lesson.

The success of this research is also supported by the average score VIIE grade student responses. Application of the method CDA responded well by VIIE grade students of SMP Negeri 1 Susut in the academic year 2015/2016. This is evident from analysis of student response data, namely, the total score of a student's response in 2489 was analyzed and obtained an average of 75.42 is in the range of 67.5 to 100 . Based on predefined criteria, response VIIE grade students are in a special category.

The response of students to the methods CDA can be considered privileged because, 1) using CDA be a quick way to understand a text especially descriptive text, 2) using CDA to provide motivation for students to receive instruction in analyzing texts especially descriptive text, 3) using CDAdapat stimulated courage students to analyze a text.

Statement of student responses can be concluded that CDA method is best used as one of the strategies to improve students' ability to understand the text in an innovative and easy. This is consistent with the statement put forward by Sulistiyo (in Trianto, 2011: 140), suggests learning strategies as specific action taken by someone to facilitate, accelerate, get more, understand more direct, more effective and more easily transferred into a situation the new one.

Which supports the theory that this method is best applied in learning to understand the text, namely the theory of constructivism. According to RJ (2010: 144) states that in theory the teacher kontuktivisme role in providing an atmosphere where students can understand and apply a knowledge, so that students work to solve problems, find everything for himself and beruaha with his ideas. In this case the teacher can provide an opportunity for their students to implement their ideas in teaching and learning in schools in particular to understand the text better understand mengkhusus more descriptive text.

This is consistent with learning theory Burner is often called the theory of solving the Canin \& Sund (in Kurniasih \& Sani, 2014: 31), which is the only way for someone to learn the techniques in performing the invention is that it has a chance to do discovery and by the invention it will strengthen memory retention. This theory is in accordance with the student response, with CDA methods students can locate and determine the text frame, meaning contained in the text thoroughly, and choose the use of the word as well as the use of the phrase used in the descriptive text, especially text.

This is also consistent with the theory of learning Ausubel. According to Ausubel (in Dirman \& Cicih, 2014: 23) concept and general information that accommodates all learning content that will be taught to students (advance organizer) provides three kinds of benefits, namely (1) provides a conceptual framework for the material to be studied, (2) serves as a bridge connecting between being studied and will be studied, (3) can help learners to understand the learning material more easily.

Based on the results obtained in the analysis of these data, in general, action research can answer questions that have been formulated, or in other words, can achieve the desired objectives. This is evident from the fulfillment of the criteria, namely 1) ability to understand the descriptive text at the end of the second cycle students have met the curriculum with the average of 87.58 and reached $100 \%$ classical completeness classified as completed.

So, based on the exposure of the above it can be concluded that the students' ability to understand the descriptive text in the subject of Indonesian increased through the implementation of CDA method VIIE grade students of SMP Negeri 1 Susut in the academic year 2015/2016.

\section{Conclusion}

Based on the results of research and discussion that has been described in chapter IV, conclusions of this study are as follows.

1) Application of Critical Discourse Analysis (CDA) can improve the ability to understand the descriptive text VIIE grade students of SMP Negeri 1 Susut in the academic year 2015/2016. It can be seen from the students' ability to understand the text in the first cycle with an average of 72.94 which included into good category, with absorption of $72.94 \%$ while the classical completeness $61 \%$ of the 20 students who completed the first cycle. While on the second cycle average student learning outcomes at 87.58 which included an excellent 
classification, with the absorption of classical completeness $87.58 \%$ and $100 \%$ of the 33 students who completed. So it can be said that an increase in the average learning outcomes by 14,64 of the first cycle to the second cycle. 2) The lesson using CDA method is as follows. The initial activity begins with preliminary activities, in that teachers begin learning greetings confirm their attendance, doing apersepsi. After the activities of introduction, followed by the Core Activities, the core activity is divided into several steps such as, (1) observed at this stage, students are given a text, and the student's task is to observe the text dekriptif that have been provided, (2) ask at this stage students ask about things that are related to the text description of how to analyze the text based on the structure supra, the macro-structure and micro-structure, (3) collecting data at this stage students are directed to analyze the descriptive text, students read text descriptions carefully, students answer / make questions about how mengaalisis descriptive text, the supra structure. Students can analyze the descriptive text of the structure of the text, starting from the introduction, then the contents of the subject, and ended with the closing, the macro structure. Students can analyze the descriptive text of the themes or topics put forward in the descriptive text, with the microstructure. Students can analyze the descriptive text of the choice of words and phrases used in the descriptive text, (4) associate this stage students to compare the results of his training, find an example of text descriptions of the various media and analyze back by smetode CDA based on the understanding that has been obtained, (5) communicate at this stage the results students mempersentasikan latihannya.Setelah core activities, namely dilanjutan last activity Closing activities. 3) Application of the method CDA was responded well by VIIE grade students of SMP Negeri 1 Susut in the academic year 2015/2016. This is evident from analysis of student response data, the total score of the response by 2489 , and then analyzed and obtained average - an average of 75.42 and was in the range of 67.5 - 100yang belonging to the privileged.

\section{References}

Arikunto. 2005. Manajemen penelitian. Jakarta: Rineka Cipta.

Dirman dan Cicih Juarsih. 2014. Teori Belajar dan Prinsip-Prinsip Pembelajaran yang Mendidik. Jakarta: Rineka Cipta.

Eriyanto.2001. Analisis Wacana Pengantar Analisis Teks Media.Yogyakarta: PT LKis Pelangi Aksara.

Kurniasih, Imas dan Berlin Sani. 2014. Sukses Mengimplementasikan Kurikulum 2013 Memahami Beragai Aspek dalam Kurikulum 2013. Jaktim: Kata Pena.

Koyan, I Wayan. 2012. Statistik Pendidikan Teknik Analisis Data Kuantitatif. Singaraja: Universitas Pendidikan Ganesha Pers.

Rosidi, Sakhban. 2007. “Analisis wacana kritis sebagai ragam paradigma kajian wacana ”Makalah disajikan pada Sekolah Bahasa atas prakarsa Himpunan Mahasiswa Islam Komisariat Universitas Islam Negeri (UIN) Malang, 15 Desember 2007.

Riyanto, Yatim. 2012. Paradigma Baru Pembelajaran: Sebagai referensi bagi pendidik dalam Implementasi Pembelajaran yang Efektif dan Berkualitas. Jakarta: Kencana

Sumiati dan Asra. 2007. Metode Pembelajaran. Bandung: CV Wacana Prima.

Trianto. 2009. Mendesain Model Pembelajaran Inovatif-Progresif. Jakarta: Kencana. 